\title{
Pengaruh Faktor-faktor yang Mempengaruhi Motivasi Terhadap Kinerja Karyawan (Survey Pada Bank Riau Kepri Cabang Tanjung Balai Karimun)
}

\author{
Adi Rahmat \\ Universitas Lancang Kuning \\ Jln. Yos Sudarso KM. 08 Rumbai-Pekanbaru \\ E-mail: a_rahmat0786@yahoo.com
}

\begin{abstract}
This research is useful to know the factors that influence the motivation on employee performance. The factors that affect motivation include compensation, direction and control, the establishment of effective working patterns and virtue. The study was conducted at the Bank Riau Riau Branch of Tanjung Balai Karimun with a total staff of 30 people. Summary table of the Model can be seen Adjust the value of R Square shows variable compensation, direction and control, the establishment of effective working patterns and virtue effect on performance of $61.7 \%$, while the rest influenced by variables / factors outside the research. While the $\mathrm{R}$ value of $81.2 \%$, which means a very strong contribution value of the variable compensation, direction and control, effective working patterns, and the virtue of the performance. Simultaneous research results showed that a significant difference between the variable compensation, direction and control, effective working patterns, and the virtue of the performance, while partially a significant difference between the variable compensation, and the virtue of the performance
\end{abstract}

Keywords: compensation, direction and control, effective working patterns, kindness and performance

Permasalahan kompleks yang dihadapi setiap organisasi baik pemerintah mau perusahaan dalam mengelola suatu organisasi adalah perbaikan dan pengembangan sumber daya manusia yang dimilikinya karena kemajuan organisasi sangat ditentukan oleh kualitas sumber daya manusia yang dimilkinya. Berbagai faktor penyebab rendahnya kualifikasi sumber daya manusia dalam suatu organisasi yang antara lain kemampuan, motivasi kerja dan pendidikan, keterampilan dan kesempatan. Faktor motivasi sebagai faktor sumber daya manusia tidak terlepas dari berbagai dimensi yang sangat menentukan dalam merangsang atau mendorong seseorang dalam melakukan pekerjaan yang ditugaskan kepadanya.

Setiap organisasi atau perusahaan, dengan visi dan misi yang ada peranan motivasi kerja sangat menentukan didalam mewujudkan visi dan misi tersebut. Berbagai faktor motivasi kerja karyawan sebagai unsur sumber daya manusia yang perlu mendapat perhatian yang sungguh-sungguh oleh para atasan dalam setiap jenjang struktur organisasi. Motivasi secara langsung menentukan dan mempengaruhi produktivitas, prestasi dan kinerja dalam pencapaian tujuan organisasi.

Bahwa dengan motivasi yang tinggi yang dimiliki setiap pegawai atau kelompok pegawai, akan lebih mudah untuk diberdayakan kearah yang efektif dan efisien dalam melaksanakan tugas dan fungsinya. Sebaliknya jika pegawai tidak termotivasi dalam melaksanakan tugas dan fungsinya, maka akan cenderung menurunkan tingkat produktivitas dan prestasi kerja, yang akan berimbas pada hasil kerja yang tidak memuaskan.

Perusahaan tidak akan dapat memaksimalkan tujuannya tanpa adanya karyawan yang kompeten, yaitu yang berdedikasi terhadap keinginan perusahaan selanjutnya. Namun terkadang dalam mencapai tujuan tersebut sering mengalami kegagalan yang salah satu penyebabnya adalah rasa ketidak puasan karyawan 
terhadap kebijakan yang ditetapkan perusahaan baik yang berbentuk material maupun non material. Apabila hal ini dibiarkan akan menyebabkan semangat dan gairah kerja karyawan akan menurun. Oleh sebab itu pimpinan perusahaaan harus memperhatikan apa yang menjadi keinginan dan kebutuhan karyawan.

Peran serta karyawan sebagai motor penggerak penyelenggaraan kegiatan perusahaan sangatlah penting disamping memerlukan penyediaan fasilitas yang dibutuhkan, untuk itu perlu adanya pengelolaan agar setiap karyawan memberikan kontribusi dan prestasi kerja yang sebaik-baiknya.

Jumlah dana pihak ketiga (berupa tabungan, giro dan depositi) yang dihimpun oleh Bank Riau Kepri Cabang Tanjung Balai Karimun dalam kurun waktu lima tahun terakhir yaitu tahun 2011 s/d 2015 dapat dilihat pada tabel di bawah ini.

Tabel. 1. Jumlah data pihak ketiga

\begin{tabular}{|c|c|c|c|}
\hline No & Tahun & $\begin{array}{c}\text { Jumlah } \\
(\mathrm{Rp})\end{array}$ & $\begin{array}{c}\text { Persentase }(\%) \\
\text { Perkembangan }\end{array}$ \\
\hline 1. & 2011 & $158.687 .000 .000,-$ & - \\
\hline 2. & 2012 & $177.171 .000 .000,-$ & 11,65 \\
\hline 3. & 2013 & $195.365 .000 .000,-$ & 10,27 \\
\hline 4. & 2014 & $159.862 .000 .000,-$ & $(18,12)$ \\
\hline 5. & 2015 & $112.223 .000 .000,-$ & $(29,8)$ \\
\hline
\end{tabular}

Sumber: Bank Riau Kepri

Dari table di atas dapat dilihat dana yang dihimpun oleh Bank Riau Kepri Cabang Tanjung Balai Karimun dari tahun 2011 ke 2012 terjadi kenaikan dana yang dihimpun oleh bank sebesar 11,65\%, pada tahun 2013 terjadi kenaikan sebesar $10,27 \%$, pada tahun 2014 dana pihak ke tiga yang dihimpun terjadi penurunan sebesar $(18,12 \%)$ dan pada tahun 2015 terjadi penurunan sebesar $(29,8 \%)$.

Motivasi berasal dari kata movere yang berarti dorongan atau mengarahkan. Dalam manajemen, motivasi hanya di tujukan pada sumber daya manusia khususnya bawahan. Motivasi mempersoalkan bagaimana mengarahkan sumber daya dan potensi bawahan agar mau bekerja secara produktif dalam mencapai dan mewujudkan tujuan yang telah ditetapkan (Hasibuan, 2011: 92).
Menurut Wibowo (2011: 379), motivasi merupakan dorongan terhadap serangkaian proses perilaku manusia pada pencapaian tujuan. Sedangkan elemen yang terkandung dalam motivasi meliputi unsur membangkitkan, mengarahkan, menjaga, menunjukkan intensitas, bersifat terusmenerus dan adanya tujuan.

Sedangkan menurut Siswanto (2011: 119), Motivasi adalah keadaan kejiwaan dan sikap mental yang memberi energi bagi untuk mendorong kegiatan mengarahkan atau menyalurkan perilaku kearah mencapai kebutuhan yang memberi kepuasan atau mengurangi ketidak seimbangan. Dari pendapat tersebut dapat diketahui bahwa motivasi adalah sesuatu yang memberikan dorongan atau semangat.

Selanjutnya menurut Notoatmodjo (2009: 115), motivasi adalah suatu alasan (reasoning) seseorang untuk bertindak dalam rangka memenuhi kebutuhan hidup.

Menurut Terry (2011: 168), menyatakan motivasi menyangkut perilaku manusia dan merupakan sebuah unsur yang vital dalam manajemen. Ia dapat didefinisikan sebagai membuat seseorang menyelesaikan pekerjaan dengan semangat, karena orang itu ingin melakukannya.

Sedangkan Mangkunegara (2011: 93), motif merupakan suatu dorongan kebutuhan dalam diri pegawai yang perlu dipenuhi agar pegawai tersebut dapat menyesuaikan diri terhadap lingkungannya, sedangkan motivasi adalah kondisi yang menggerakkan pegawai agar mampu mencapai tujuan dari motifnya.

Sedangkan menurut Kadarisman (2012: 278), motivasi adalah penggerak atau pendorong dalam diri seseorang untuk berperilaku dan bekerja dengan giat dan baik sesuai dengan tugas dan kewajiban yang telah diberikan kepadanya.

Dari berbagai pendapat tentang motivasi, tampak jelas bahwa seseorang mau bekerja dalam suatu badan apabila ada suatu dorongan atau motivasi yang diterima dari perusahaan atau organisasi tersebut. Semakin diperhatikan tujuan perseorangan dalam suatu badan usaha maka akan 
semakin giat pula dalam melakukan tugasnya.

Sedangkan menurut Sudarwan Danim (2004: 17), secara umum motivasi dapat diklasifikasikan dalam 4 jenis yaitu:

1. Motivasi positif

Motivasi positif didasari atas keinginan manusia untuk mencari keuntungankeuntungan tertentu. Motivasi positif merupakan proses pemberian motivasi atau usaha membangkitkan motif, dimana hal itu diarahkan pada usaha untuk mempengaruhi orang lain agar dia bekerja secara baik dan antusias dengan cara memberikan keuntungan tertentu kepadanya.

2. Motivasi negatif

Motivasi negatif sering dikatakan sebagai motivasi yang bersumber dari rasa takut. Motivasi negatif yang berlebihan akan membuat organisasi tidak mampu mencapai tujuan. Personalia organisasi menjadi tidak kreatif, serba takut, dan serba terbatas geraknya.

3. Motivasi dari dalam

Motivasi dari dalam timbul pada diri pekerja waktu dia menjalankan tugastugas atau pekerjaan dan bersumber dari dalam diri pekerja itu sendiri. Dengan demikian berarti juga bahwa kesenangan pekerja muncul pada waktu dia bekerja dan dia sendiri menyenangi pekerjaannya itu.

4. Motivasi dari luar

Motivasi dari luar adalah motivasi yang muncul sebagai akibat adanya pengaruh yang ada diluar pekerjaan dan dari luar diri pekerja itu sendiri. Motivasi dari luar biasanya dikaitkan dengan imbalan.

Ciri-ciri motif individu menurut Edi

Sutrisno (2011: 115) adalah:

1. Motif adalah majemuk

Dalam suatu perbuatan tidak hanya mempunyai satu tujuan tetapi beberapa tujuan yang berlangsung bersama-sama.

2. Motif dapat berubah-ubah

Motif bagi seseorang kerap mengalami perubahan. Ini disebabkan karena keinginan manusia selalu sesuai dengan kebutuhan atau kepentingannya.
3. Motif berbeda-beda bagi individu Dua orang yang melakukan pekerjaan yang sama, tetapi ternyata terdapat perbedaan motif.

4. Beberapa motif tidak disadari oleh individu

Banyak tingkah laku manusia yang tidak disadari oleh perilakunya. Sehingga beberapa dorongan yang muncul sering kali karena berhadapan dengan situasi yang kurang menguntungkan lalu ditekan di bawah sadarnya.

Menurut Siswanto (2011: 124), pada umumnya dalam organisasi motivasi dipengaruhi oleh empat faktor, yaitu:

1. Kompensasi

Salah satu bentuk yang paling sering diberikan kepada karyawan adalah berupa kompensasi. Kompensasi yang diberikan kepada karyawan biasanya berwujud uang. Kompensasi sebagai kekuatan untuk memberi motivasi selalu mempunyai reputasi atau nama baik dan memang sudah selayaknya demikian. Meskipun sama sekali kurang tepat bahwa semua orang akan berbuat apa saja untuk meningkatkan pendapatan uang mereka, namun selama beberapa dekade terbukti bahwa hampir semua orang akan berbuat apa saja untuk mencegah agar sumber pendapatan mereka tidak diambil orang.

2. Pengarahan dan pengendalian

Pengarahan dimaksudkan menentukan bagi karyawan mengenai apa yang harus mereka kerjakan dan apa yang tidak harus mereka kerjakan. Sedangkan pengendalian dimaksudkan menentukan bahwa karyawan harus mengerjakan halhal yang telah diinstruksikan.

3. Penetapan pola kerja yang efektif Pola kerja yang kurang sesuai dengan tindakan dan komposisi diakui sebagai masalah yang berat. Hal ini bisa menjadi lebih negatif, karena karyawan makin lama lebih muda dan berpendidikan lebih tinggi dari pada dasawarsa sebelumnya. 
4. Kebajikan

Kebajikan dapat didefenisikan sebagai suatu tindakan yang diambil dengan sengaja oleh manajemen untuk mempengaruhi sikap atau perasaan para karyawan. Dengan kata lain, kebajikan adalah usaha untuk membuat karyawan bahagia.

Kinerja Karyawan: diartikan sebagai persepsi pemilik/ pengelola terhadap hasilhasil pribadi dan pekerjaan dari karyawan. meliputi: kuantitas pekerjaan, kualitas pekerjaan, inisiatif dalam pekerjaan dan peluang promosi.

Salah satu difinisi tentang kinerja oleh Hadari Nawawi (2008:62) dalam bukunya Evaluasi Kinerja. Kinerja adalah kuantitas dan kualitas pencapaian tugas-tugas, baik yang dilakukan individu, kelompok maupun organisasi. Defenisi kinerja menurut Kamus Besar Bahasa Indonesia adalah Kinerja adalah hasil yang dicapai seorang pegawai dalam melaksanakan tugas yang dibebankan kepadanya.

Hadari Nawawi juga menyatakan pengertian kinerja dalam handouts evaluasi dan manajemen kinerja, kinerja adalah energi penggerak dalam bekerja, yang bersumber dari tiga domain yg terdapat dalam perpaduan fifik dan psikis manusia sbb :

1. Domain Kognitif (Pengetahuan, Pemahaman, Ana lisis, Sintesis, Aplikasi dan Evaluasi atau Kecerdasan Intelektual (kinerja untuk berprestasi dan bersaing dalam meraih sukses).

2. Domain Afekif - Kecerdasan Emosional/ Sosial - Ke cerdasan Enterpreneur - Kecerdasan Adversitas dan Kecerdasan Spiritual. (kinerja untuk berprestasi melalui kerjasama dalam meraih sukses).

3. Domain Psiko Motor (Gerak motorik/ fisik sebagai kinerja yang digerakan oleh kedua doman tsb di atas) khususnya dalam bekerja yang diwujudkan berupa perilaku Un-Skill - Skill - Ahli/ Profesional - Spesialis - Super Spesialis. Menurut Lavasque dalam Handouts Hadari Nawawi (2010:38), Kinerja adalah (a) segala sesuatu yang dikerjakan seseorang (b) sesuatu yang dicapai, (c) Prestasi atau hasil dalam melaksanakan fungsi suatu pekerjaan.

Zainun (2001) mengemukakan bahwa faktor-faktor yang mempengaruhi kinerja pegawai antara lain disebabkan motivasi, kemampuan, lingkungan dan iklim organisasi. Lebih lanjut dikemukakan oleh Zainun bahwa motivasi merupakan kondisi psikologis yang mendorong seseorang untuk memenuhi kebutuhannya akan sesuatu. Kemampuan merupakan suatu unsur pelaksana kerja yang diperlukan untuk memungkinkan para pegawai bekerja dengan cara tertentu yang mengandung berbagai unsur seperti keterampilan manual dan intelektual. Unsur ini juga mencerminkan, latihan dan pengalaman yang dituntut sesuai rincian kerja. Selain itu kinerja pegawai juga dipengaruhi oleh lingkungan dan iklim organisasi. Faktorfaktor lingkungan yang berpengaruh terhadap kinerja pegawai antara lain : budaya, politik, ekonomi, teknologi dan sosial. Pengaruh itu dapat bersifat langsung ataupun tidak langsung.

Berpijak pada pengukuran konsep tersebut maka dalam penelitian ini pengukuran kinerja mengacu pada kualitas, kuantitas dan ketepatan waktu menjadi satu pengukuran yaitu kecakapan (kemampuan) pegawai dalam melaksanakan tugas (pekerjaan).

Model yang digunakan di dalam penelitian adalah sebagai berikut:

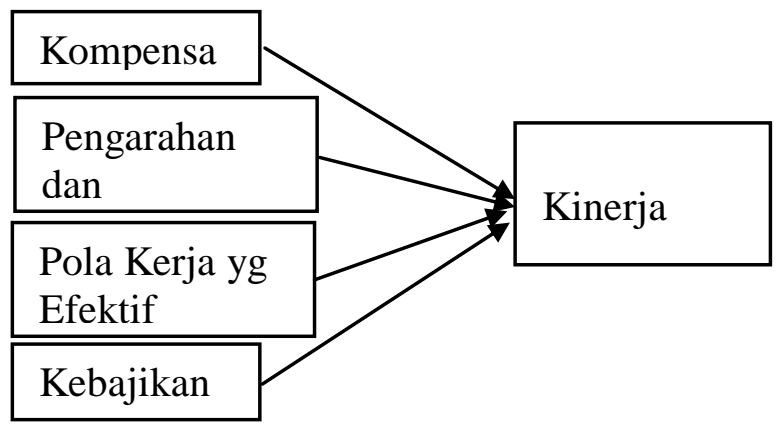

\section{Gambar 1. Model Penelitian}

Hipotesis dalam penelitian ini adalah sebagai berikut:

Ho = Tidak terdapat pengaruh faktor-faktor yang mempengaruhi motivasi terhadap 
kinerja.

$\mathrm{Ha}=$ Terdapat pengaruh faktor-faktor yang mempengaruhi motivasi terhadap kinerja.

\section{METODE}

Penelitian dilakukan dengan mengPopulasi untuk penelitian ini berjumlah 30 orang. Untuk menentukan ukuran sampel dari suatu populasi, terdapat bermacammacam cara yang dikemukakan para ahli. Pengambilan sampel dilakukan dengan teknik sampel jenuh, hal ini dilakukan karena jumlah anggota populasi relatif kecil. Jumlah sampel dalam penelitian ini sebanyak 30 orang sesuai dengan jumlah populasi.

Untuk memperoleh data dalam penelitian ini dipergunakan teknik pengumpulan data yaitu:

a. Teknik pengumpulan data kepustakaan. Teknik ini digunakan untuk mengumpulkan data mengenai teoriteori, konsep-konsep yang behubungan dengan variabel penelitian dari bukubuku dan literature yang relevan.

b. Teknik Pengumpulan Data Lapangan. Teknik ini digunakan untuk menemukan data empirik dengan menggunakan angket/ kuesioner dengan Skala Likert. Menurut Kinnear (1988) yang dikutip dalam buku Metodologi Penelitian untuk Skripsi dan Tesis Bisnis (Husein Umar, 2008:70-71), Skala Likert ini berhubungan dengan pernyataan tentang sikap seseorang terhadap sesuatu. Responden diminta mengisi pernyataan dalam skala ordinal. Skala pengukuran adalah Skala Likert yang dibagi kedalam lima, pengukuran, dimana skala pengukurannya menggunakan skala 1 sampai dengan 5 (skala likert). Dimana angka 1 mewakili Sangat Tidak Setuju (STS) sampai dengan angka mewakili Sangat Setuju (SS).

Pada penelitian ini metode yang digunakan adalah dengan menggunakan analisis regresi linier berganda. Adapun rumus regresi linier berganda :

$Y=\alpha+\beta_{1} X_{1}+\beta_{2} X_{2}+\beta_{3} X_{3}+\beta_{4} X_{4}$

Keterangan :

$\mathrm{X}_{1}$ : Kompensasi
$\mathrm{X}_{2}$ : Pengarahan dan pengendalian

$\mathrm{X}_{3}$ : Pola kerja yang efektif

$\mathrm{X}_{4}$ : Kebajikan

$\mathrm{Y}$ : Kinerja

\section{HASIL}

Tabel 2. Output SPSS Model Summary Variabel kompensasi, pengarahan dan pengendalian, pola kerja yang efektif, kebajikan dan terhadap kinerja.

\begin{tabular}{|l|r|r|r|c|}
\hline Model & \multicolumn{5}{|c|}{ Model Summary $^{\mathrm{b}}$} & R Square & $\begin{array}{c}\text { Adjusted R } \\
\text { Square }\end{array}$ & $\begin{array}{c}\text { Std. Error of the } \\
\text { Estimate }\end{array}$ \\
\hline 1 & $.812^{\mathrm{a}}$ & .660 & .617 & 1.34537 \\
\hline
\end{tabular}

a. Predictors: (Constant), Total_X4, Total_X3, Total_X1, Total_X2

b. Dependent Variable: Total_Y

Sumber : Data primer, Olahan SPSS

Dari tabel Model Summary dapat dilihat nilai Adjusted R Square sebesar 0,617. hal ini menunjukkan bahwa kompensasi, pengarahan dan pengendalian, pola kerja yang efektif, dan kebajikan berpengaruh sebesar $61,7 \%$ terhadap kinerja, sedang sisanya sebesar $37,3 \%$ adalah pengaruh variabel lain yang tidak diteliti. Dimana nilai $\mathrm{R}=0,812$ artinya merupakan nilai kontribusi yang sangat kuat dari variabel kompensasi, pengarahan dan pengendalian, pola kerja yang efektif, dan kebajikan terhadap kinerja yaitu sebesar 81,2\%.

Tabel 3. Output SPSS Anova Variabel kompensasi, pengarahan dan pengendalian, pola kerja yang efektif, dan kebajikan terhadap kinerja.

\begin{tabular}{|c|c|c|c|c|c|c|}
\hline \multicolumn{7}{|c|}{ ANOVA $^{\mathrm{a}}$} \\
\hline Mod & & Sum of Squares & Df & Mean Square & $\mathrm{F}$ & Sig. \\
\hline \multirow{3}{*}{1} & Regression & 112.403 & 4 & 28.101 & 15.525 & $.000^{\mathrm{b}}$ \\
\hline & Residual & 57.921 & 32 & 1.810 & & \\
\hline & Total & 170.324 & 36 & & & \\
\hline
\end{tabular}

a. Dependent Variable: Total_Y

b. Predictors: (Constant), Total_X4, Total_X3, Total_X1, Total_X2

Sumber : Data primer, Olahan SPSS

Uji $F$ dilakukan untuk mengetahui hubungan secara serentak, dari hasil output SPSS pada tabel 3 dapat dilihat nilai signifikan variabel kompensasi, pengarahan dan pengendalian, pola kerja yang efektif, dan kebajikan terhadap kinerja secara simultan menunjukan nilai sig. 0,000 $(<$ $0,05)$ pada tingkat $\alpha=5 \%$. Hal ini 
menunjukan bahwa terdapat pengaruh yang signifikan antara variabel kompensasi, pengarahan dan pengendalian, pola kerja yang efektif, dan kebajikan terhadap kinerja. Tabel 4.Output SPSS Coefficients Variabel kompensasi, pengarahan dan pengendalian, pola kerja yang efektif, dan kebajikan terhadap kinerja.

\begin{tabular}{|c|c|c|c|c|c|c|}
\hline \multirow{3}{*}{ Mode } & & & & \multicolumn{2}{|c|}{ Coefficients $^{\mathrm{a}}$} & \multirow{3}{*}{ Sig. } \\
\hline & & \multicolumn{2}{|c|}{$\begin{array}{l}\text { Unstandardized } \\
\text { Coefficients }\end{array}$} & $\begin{array}{c}\text { Standardized } \\
\text { Coefficients }\end{array}$ & $t$ & \\
\hline & & $\mathrm{B}$ & Std. Error & Beta & & \\
\hline \multirow{5}{*}{1} & (Constant) & 1.344 & 4.072 & & .330 & .743 \\
\hline & Total_X1 & .270 & .125 & .232 & 2.157 & .039 \\
\hline & Total_X2 & .025 & .121 & .024 & .207 & .837 \\
\hline & Total_X3 & .014 & .116 & .012 & .118 & .907 \\
\hline & Total_X4 & .631 & .102 & .722 & 6.193 & .000 \\
\hline
\end{tabular}

Sumber : Data primer, Olahan SPSS

Pada tabel coefficients variabel kompensasi, pengarahan dan pengendalian, pola kerja yang efektif, dan kebajikan terhadap kinerja, terlihat:

a. $t$ hitung $(2,157)$ dengan $t$ tabel $(2,001)$. Dikarenakan nilai $\mathrm{t}$ hitung $>\mathrm{t}$ tabel, maka dapat disimpulkan Ho ditolak artinya ada pengaruh yang signifikan antara kompensasi terhadap kinerja.

b. $t$ hitung $(0,207)$ dengan $t$ tabel $(2,001)$. Dikarenakan nilai $\mathrm{t}$ hitung $<\mathrm{t}$ tabel, maka dapat disimpulkan Ho diterima artinya tidak ada pengaruh yang signifikan antara pengarahan dan pengendalian terhadap kinerja.

c. t hitung $(0,118)$ dengan $t$ tabel $(2,001)$. Dikarenakan nilai $\mathrm{t}$ hitung $<\mathrm{t}$ tabel, maka dapat disimpulkan Ho diterima artinya tidak ada pengaruh yang signifikan antara penetapan pola kerja yang efektif terhadap kinerja.

d. $t$ hitung $(6,193)$ dengan $t$ tabel $(2,001)$. Dikarenakan nilai $\mathrm{t}$ hitung $>\mathrm{t}$ tabel, maka dapat disimpulkan Ho ditolak artinya ada pengaruh yang signifikan antara kebajikan terhadap kinerja.

\section{PEMBAHASAN}

Berdasarkan hasil penelitian yang menunjukkan adanya pengaruh yang signifikan antara variabel-variabel kompensasi, pengarahan dan pengendalian, pola kerja yang efektif, dan kebajikan terhadap kinerja. Maka dapat dibuat pembahasan dari hasil penelitian tersebut, Adapun tujuan pemberian motivasi kepada karyawan menurut Hasibuan (2011: 146) adalah sebagai berikut:

1. Meningkatkan moral dan kepuasan kerja karyawan

2. Meningkatkan produktivitas kerja karyawan

3. Mempertahankan kestabilan karyawan perusahaan

4. Meningkatkan kedisiplinan karyawan

5. Mengefektifkan pengadaan karyawan

6. Menciptakan suasana hubungan kerja yang baik

7. Meningkatkan loyalitas, kreatifitas dan partisipasi karyawan

8. Mempertinggi rasa tangung jawab karyawan terhadap tugasnya

9. Meningkatkan tingkat kesejahteraan karyawan

10. Meningkatkan efisiensi dalam penggunaan alat dan bahan baku

Sedangkan menurut Kadarisman (2012: 292) pada hakikatnya tujuan pemberian motivasi kerja kepada pegawai adalah untuk:

1. Mengubah perilaku karyawan sesuai dengan keinginan perusahaan.

2. Meningkatkan gairah dan semangat kerja

3. Meningkatkan disiplin kerja

4. Meningkatkan prestasi kerja

5. Meningkatkan rasa tanggung jawab

6. Meningkatkan produktivitas dan efisiensi

7. Menimbuhkan loyalitas pada perusahaan

Menurut Mangkunegara (2011: 100), terdapat beberapa prinsip dalam memotivasi kerja pegawai yaitu:

1. Prinsip partisipasi

Dalam upaya memotivasi kerja, pegawai perlu diberikan kesempatan ikut berpartisipasi dalam menentukan tujuan yang akan dicapai oleh pemimpin.

2. Prinsip komunikasi

Pemimpin mengkomunikasikan segala sesuatu yang berhubungan dengan usaha pencapaian tugas, dengan informasi yang jelas, pegawai akan lebih mudah 
dimotivasi kerjanya.

3. Prinsip mengakui andil bawahan

Pemimpin mengakui bahwa bawahan (pegawai) mempunyai andil di dalam usaha pencapaian tujuan.

4. Prinsip pendelegasian wewenang

Pemimpin yang memberikan otoritas atau wewenang kepada pegawai bawahan untuk sewaktu-waktu dapat mengambil keputusan terhadap pekerjaan yang dilakukannya.

5. Prinsip member perhatian

Pemimpin memberikan perhatian terhadap apa yang diinginkan pegawai bawahan, akan memotivasi pegawai bekerja apa yang diharapkan oleh pimpinan.

Sedangkan menurut Sudarwan Danim (2004: 41), cara yang dapat dilakukan untuk meningkatkan motivasi bawahan yang dijadikan indikator motivasi adalah sebagai berikut:

1. Rasa hormat

Berikan rasa hormat secara adil, demikian juga penghargaan. Adil tidak berarti sama rata. Dengan demikian, dilihat dari aspek prestasi kerja, atasan tidak mungkin memberikan pengahargaan atau rasa hormat yang sama kepada semua orang. Berikan penghargaan kepada karyawan atas dasar prestasi, kepangkatan, pengalaman dan sebagainya.

2. Informasi

Berikan informasi kepada karyawan mengenai aktivitas organisasi, terutama tentang apa yang harus mereka lakukan dan bagaimana cara melakukannya. Informasikan standar prestasi, tentukan dan beritahukan apa yang harus diperbuat.

3. Perilaku

Usahakan mengubah perilaku sesuai dengan harapan bawahan dan dengan demikian dia mampu membuat bahwa berperilaku atau berbuat dengan apa yang diharapkan organisasi. Berikan pujian kepada bawahan yang rajin dan berprestasi sehingga mereka berusaha lebih baik.

4. Hukuman

Berikan hukuman kepada staf yang bersalah di ruang yang terpisah. Jangan menghukum bawahan di depan orang lain, baik di depan rekan kerja maupun orang luar. Hukuman yang diberikan di depan orang lain dapat menimbulkan frustasi dan merendahkan martabat.

5. Perintah

Perintah yang diberikan kepada bawahan sebaiknya bersifat tidak langsung. Adakalanya perintah yang seharusnya di-ya-kan, karena disampaikan secara salah akibatnya ditidak-kan. Berikanlah perintah laksana ajakan, dan jika perlu diawali dengan contoh.

6. Perasaan

Interaksi antara atasan dan bawahan adalah interaksi antar-manusia. Manusia adalah insan yang penuh perasaan. Tanpa mengetahui bagaimana harapan bawahan dan perasaan apa yang ada pada diri mereka, sangat sukar bagi pimpinan untuk memotivasi bawahan.

Untuk mengatasi masalah kinerja karyawan perlu dilakukan penilaian kinerja. Metode penilaian kinerja dapat dilakukan dengan cara berorientasi masa lalu atau berorientasi masa yang akan datang. Penilaian kinerja berorientasi masa lalu merupakan penilaian berdasarkan hasil yang dicapai, penilaian kerja berorentasikan masa yang akan datang adalah penilaian kinerja karyawan saat ini dan penetapanpenetapan sasaran kerja dimasa yang akan datang yaitu: penilaian diri (self assesment), penilaian pendekatan management by objective dan pusat-pusat penilaian.

Pegawai yang melakukan penilaian terhadap diri sendiri berusaha seobjektif mungkin untuk menjelaskan antara lain: Apa tugas pokonya, pengetahuan dan keterampilan yang dituntut oleh tugas, kaitannya dengan tugasnya dengan tugastugas orang lain, dalam hal apa pegawai yang bersangkutan merasa berhasil, kesulitan yang dihadapi dan langkahlangkah perbaikan apa yang perlu ditempuh.

Adapun jenis-jenis penilaian kinerja sebagai berikut : 
1. Penilaian hanya oleh atasan

* cepat dan langsung

* dapat mengarah ke distorsi karena pertimbangan-pertimbangan pribadi.

2. Penilaian oleh kelompok lini : atasan dan atasannya lagi bersama -sama membahas kinerja dari bawahannya yang dinilai.

* obyektifitas lebih lebih akurat dibandingkan kalau hanya oleh atasannya sendiri.

* Individu yang dinilai tinggi dapat mendominasi penilaian.

3. Penilaian oleh kelompok staf : atasan meminta satu atau lebih individu untuk bermusyawarah dengannya; atasan langsung yang membuat keputusan akhir.

4. Penilaian melalui keputusan komite : sama seperti pada pola sebelumnya kecuali bahwa manajer yang bertanggung jawab tidak lagi mengambil keputusan akhir; hasil didasarkan pada pilihan mayoritas.

5. Penilaian berdasarkan peninjauan lapangan : sama sepeti kelompok staf, namun melibatkan wakil dari pimpinan pengembangan atau departemen SDM yang bertindak sebagai peninjau independen

6. Penilaian yang dilakukan oleh bawahan dan sejawat.

\section{SIMPULAN}

Berdasarkan hasil penelitian yang telah dilakukan oleh penulis pada uraian bab-bab sebelumnya, mengenai faktor-faktor mempengaruhi motivasi kerja karyawan pada PT Bank Riau Kepri cabang Tanjung Balai Karimun, maka berikut ini penulis dapat mengambil kesimpulan:

1. Nilai signifikansi 0,000 , nilai ini dibawah nilai standar 0,05 maka dapat disimpulkan Ho ditolak artinya ada pengaruh yang signifikan antara kompensasi, pengendalian dan pengarahan, penetapan pola yang efektif dan kebajikan terhadap kinerja.

2. $Y^{\prime}=a+b_{1} X_{1}+b_{2} X_{2}+b_{3} X_{3}+b_{4} X_{4}$ $Y^{\prime}=1,344+0,270 X_{1}+0,025 X_{2}+$
$0,014 X_{3}+0,631 X_{4}$

Angka-angka dapat diartikan sebagai berikut: Konstanta sebesar 1,344; artinya kompensasi, pengarahan dan pengendalian, pola kerja yang efektif, kebajikan nilainya adalah nol, maka kinerja nilainya positif sebesar 1,344. Koefisien regresi kompensasi sebesar 0,270; artinya jika motivasi kerja mengalami kenaikan 1 satuan, maka kinerja akan mengalami kenaikan sebesar 0,270. Koefisien bernilai positif artinya terjadi hubungan positif antara kompensasi dengan kinerja, artinya semakin besar nilai kompensasi maka semakin naik nilai kinerja. Koefisien regresi pengarahan dan pengendalian sebesar 0,025; artinya jika kinerja mengalami kenaikan 1 satuan, maka kinerja akan mengalami kenaikan sebesar 0,025. Koefisien bernilai positif artinya terjadi hubungan positif antara pengarahan dan pengendalian dengan kinerja, artinya semakin besar nilai pengarahan dan pengendalian maka semakin naik nilai kinerja. Koefisien regresi penetapan pola kerja yang efektif sebesar 0,014; artinya jika kinerja mengalami kenaikan 1 satuan, maka motivasi kerja akan mengalami kenaikan sebesar 0,014. Koefisien bernilai positif artinya terjadi hubungan positif antara penetapan pola kerja yang efektif dengan kinerja, artinya semakin besar nilai penetapan pola kerja yang efektif maka semakin naik nilai kinerja. Koefisien regresi kebajikan sebesar 0,631; artinya jika kebajikan kerja mengalami kenaikan 1 satuan, maka kinerja akan mengalami kenaikan sebesar 0,631. Koefisien bernilai positif artinya terjadi hubungan positif antara kebajikan dengan kinerja, artinya semakin besar nilai kebajikan maka semakin naik nilai kinerja

3. Adjusted R Square sebesar 0,617. hal ini menunjukkan bahwa motivasi, pengarahan dan pengendalian, pola kerja yang efektif, dan kebajikan berpengaruh sebesar $61,7 \%$ terhadap 
motivasi kerja, sedang sisanya sebesar $37,3 \%$ adalah pengaruh variabel lain yang tidak diteliti

Dari kesimpulan penelitian diatas, maka penulis dapat memberikan masukan sebagai berikut:

1. Untuk memotivasi pegawai secara efektif ada tiga strategi yang dapat dipergunakan untuk meningkatkan motivasi kerja pegawai, yaitu sebagai berikut: strategi penggunaan pendekatan, metode dan menyatukan semua cara untuk memotivasi.

2. Metode yang dipergunakan meliputi mempergunakan uang sebagai penghargaan dan insentif, menyebutkan persyaratannya, mengembangkan keterikatan, memotivasi melalui pekerjaan itu sendiri, menghargai dan mengakui prestasi kerja, mengembangkan kepemimpinan, membangun kerjasama antar kelompok, melatih dan mengembangkan setiap orang, serta menghilangkan hal-hal yang negatif.

3. Diharapkan kepada PT Bank Riau Kepri untuk kedepan lebih meningkatkan pengendalian dan pengarahan serta penetapan pola kerja yang efektif kepada karyawan sehingga tujuan dari perusahaan dapat dicapai dengan lebih baik

\section{DAFTAR RUJUKAN}

A.A.Anwar Prabu Mangkunegara. 2011. Manajemen Sumber Daya Manusia Perusahaan. PT.Remaja Rosda Karya, Bandung.

Buchari Zainun. 2001. Manajemen Sumber Daya Manusia Indonesia. Gunung Agung Jakarta.

Danim, Sudarman 2004. Motivasi Kepemimpinan dan Efektivitas Kelompok. Penerbit Rineka Cipta.

Hasibuan, Malayu S.P., 2011. Manajemen Sumber Daya Manusia. Bumi Aksara, Jakarta.
Kadarisman, M, 2012. Manajemen Pengembangan Sumber Daya Manusia, Rajawali Pers, Jakarta.

Nawawi, Hadari. 2008. Perencanaan SDM Untuk Organisasi Profit Yang Kompetitif. Yogyakarta: Gadjah Mada University Press. . 2010. Handouts Evaluasi dan Manajemen Kinerja Program Magister Manajemen Universitas Putra Indonesia "YPTK" Padang.

Siswanto. 2011. Pengantar Manajemen. Jakarta: Bumi Aksara.

Soekidjo, Notoatmodjo. 2009. Pengantar Sumber Daya Manusia. Jakarta: Rhineka Cipta.

Sutrisno, Edy. 2011. Manajemen Sumber Daya Manusia. Jakarta: Kencana.

Umar, Husein. 2007. Metodologi penelitian Untuk Skripsi dan Tesis Bisnis. Jakarta: Raja Grafindo Persada. 